\title{
From Pentecost to 'inner healing' Religious change and Pentecostal developments in the post-socialist Lithuanian Catholic milieu
}

th $\mathrm{n}$ this article the author describes the religious change that took place in the Catholic milieu of post-Soviet Lithuania. Following the arrival of global Pentecostal trends to the country a Catholic form of Pentecostalism, known as Catholic Charismatic Renewal (CCR) also arrived. The author describes what changes the CCR brought and how the Pentecostal developments paved the way for this other movement to emerge. Dynamic developments of the CCR unexpectedly took a turn towards the discourse and practice of healing, which triggered the emergence of another movement, known as the Inner Healing Movement (IHM). Being inseparable from its Pentecostal roots the movement, nevertheless, has become a vernacular, specifically Catholic, practice which no longer seeks for the signs of Pentecostal authenticity but redefines the Pentecostal message, directing it towards healing discourses and practices.

\section{Introduction}

Popular Catholic practices throughout the world seem to be turning towards placing an emphasis on the 'healing capacity' of Christianity. This trend is not limited to one movement but is noticeable in various 'schools' of Catholic spirituality. After spending several years researching the so-called Catholic Charismatic Renewal (CCR), I would argue that the trend can be traced to this particular movement, which began in the US in the 1960 s and resonated with global Pentecostal trends. In this article I present some ethnographical research and discuss exactly how the CCR entered Lithuania's post-Soviet religious realm. I also discuss how it triggered the development of the Inner Healing movement (IHM) which now exceeds the definition of a movement alone and is likely to have a significant influence on vernacular popular Catholic piety.
Not only the development of Pentecostal Christianity, but the overall development of religion in Eastern Europe at the end of the Soviet era would be an exciting topic of inquiry for many scholars of the social sciences. Religion, as a banned activity under the militant secularist regime, was a part of the identity of the resistance and a popular topic in Lithuania. After the collapse of the Soviet Union, the hitherto suppressed religious sensibilities burst out and were expressed in a variety of religions, cults and sects. Religion was everywhere. Catholic priests participated in TV and radio shows, visited schools and gave public lectures which attracted crowds of people. On their way home from work people would encounter street preachers, and on Saturdays or Sundays they would often hear loud Christian singing coming from neighbouring apartments. Issues related to Christianity were frequently taken onto the streets, advertised in the media, on the sides of buses and elsewhere. Bible-based religious communities mushroomed all over Lithuania.

Quite a few of those communities were related to the global Pentecostal movement, even if they did not directly associate themselves with Pentecostalism. The most popular of these was the 'Word of Life.' This is a typical Scandinavian type of neo-Pentecostal community, influenced by Ulf Ekman's teaching. There were also many similar communities, which were recruiting members by means of individual proselytism and street outreach. What these communities in fact were 'selling' was not so much a theology, but rather a 'genuine' Christian experience. This was the driving force of their proselytism and a 'buy-in' for conversion. The search for 'genuine' Christian experiences was also the reason Christians migrated between these communities. The focus in all of these processes was precisely the pursuit of Christian experiences, which in their 
essence were almost exclusively Pentecostal. ${ }^{1}$ This is the issue which is often overlooked when discussing post-Socialist religious developments. What scholars of religion see and examine in the post-Socialist milieu largely depends on what the scholar is particularly looking for - be they post-Socialist trends or religion. While the two are undoubtedly interdependent, the emergence of Pentecostal Christianity in the region was definitely not caused by the collapse of the Soviet regime. This is a global trend which could not take root earlier because of the militant secularism of the Soviet State, but which sprang up with all its potential as soon as the socio-political conditions for its emergence improved.

Global Pentecostal trends (GPT) in Lithuania, despite their frenzied explosion, surprisingly went unnoticed among local social sciences scholars. This is not to say that they overlooked religious activity altogether. But sociologists focused on changing religious values (Žilinskaite 2000), or on the new religious movements in general (Ališauskiene 2006). Others looked at the growth of religiosity in the region, analysing census data, or issues of religious freedom, pluralism and the dominance of the Catholic Church in Lithuania (see Ališauskiene 2011, Schröder 2009). Global Pentecostal trends were intimately involved in these frameworks. The closest we came to a recognition of GPT in Lithuania would be Lanksauskas's study of the Word of Faith Community (see Lankauskas 2008 and 2009). He examined the community within its own context and in the broader framework of charismatic Christianity. However, I would argue that his study is concerned with postcolonial discourses rather than GPT. How did it happen that such a rapidly proliferating and vivid phenomenon was not identified, let alone properly researched, by Lithuanian social sciences scholars? I would give several reasons:

1) The Pentecostal phenomenon, and especially its global trends, are historically recent, as is the attention given to it by scholars (see Anderson 2010: 3-9).

2) The fluid nature of Pentecostalism as an object of study is so dynamic that 'before the ink on

1 For a broader examination of this, see Pelkmans 2009. Note that the majority of the essays in that volume are at least remotely linked with global Pentecostalist trends. research reports is dry, new developments have already presented themselves' (ibid.).

3) Anthropology historically has focused on Pentecostalism in the non-Western world, as if it were a remote, exotic wonder.

4) The difficulty or rather inability to 'connect the dots' on Pentecostal trends in the West is probably due to the inherently problematic, even neglectful, relationship between the social sciences and Christianity (see Cannell 2005, 2006; Hann 2007; Robbins 2003).

5) Finally, the nature of the research field of GPT is that of a balance between interdisciplinarity and multidisciplinarity, which in itself is a 'sandwich' of challenges. Interdisciplinary research itself is notoriously problematic among social scientists and they are often reluctant to engage in such an endeavour. However, it seems that the complexity of Pentecostal phenomena calls for no less than that. So what is going on in reality is that multiple disciplines of the social sciences and the humanities are approaching one or other Pentecostal phenomenon or trend independently, hardly finding, if at all looking for, any common interdisciplinary ground. This, I suggest, distorts the complexity of Pentecostalism, making it difficult to see each trend as a piece in one global puzzle. This is exactly why, at least in Lithuania, scholars were able to grasp and research separate trends of the post-Soviet religious developments of Christianity, yet failed to recognise not only that these parts fit together, but also that this state of affairs leads on to something more complex and substantial altogether.

\section{What is the Inner Healing movement?}

As mentioned above, the IHM was nurtured by the Western Catholic Charismatic Renewal. Studies by Thomas Csordas (1997a, 1997b), Richard Bord and Joseph Faulkner (1983) and Meredith McGuire (1982) so far stand out as the most comprehensive anthropological accounts of that movement. Although none of them at the time referred to inner healing, nevertheless their studies grasp the emergence of the trend. Csordas gives ethnographic examples of the practice called 'healing of memories' (Csordas 1997b: 74-141), which later came to be called 'inner healing. Bord and Faulkner assume 
that as the CCR has matured, 'then the gift of healing has come to the forefront' (1983: 93). This, as we can see now, was apparently more than a 'maturation' and more of a turn towards a healing discourse in the Catholic Church. Moreover, the emphasis on the 'healing capacity' of Christianity seems to be escaping the initial discursive constraints of Pentecostal Catholicism and becoming a global trend as well as an element of popular Catholic piety.

The first time I encountered inner healing was in 1997, when sitting around a campfire with friends from the Catholic Charismatic Renewal. One of them spoke about some strange religious practices in a CCR community located somewhere in the mountains of Slovakia. He told us about the experience of a prayer session during which people went over their past traumatic or painful experiences, gradually revisiting their childhood and even embryo selves; facing and forgiving things. He also described the bizarre effect of

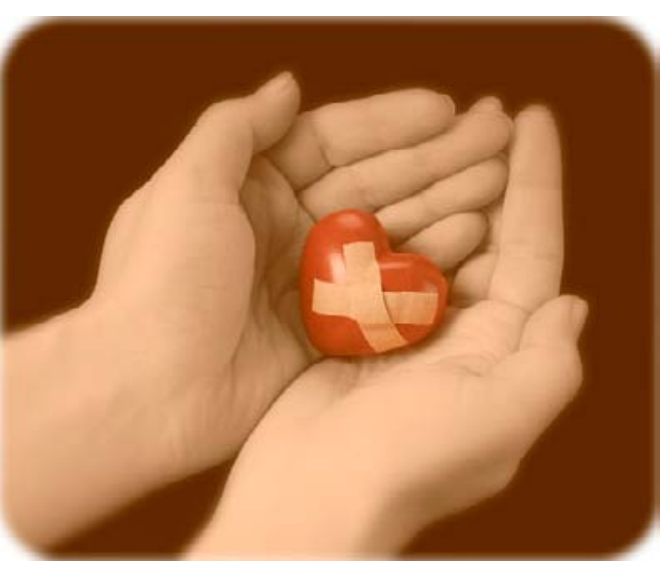
this prayer on the participants. They called this practice 'inner healing. Soon it became one of the most frequently discussed issues in the Lithuanian CCR milieu, gradually becoming the most frequent form of CCR healing practice. It also became the most popular topic at local CCR conferences and public rallies. In the year 2000, crowds of people turned out for anything associated with inner healing. It all accelerated when the CCR organisation invited a priest from India, Fr. Rufus Pereira, to come to Lithuania. Fr. Pereira was an official exorcist and an 'expert' on inner healing. During his visits, the churches in which he spoke were overcrowded and his seminars were fully booked three months in advance. The local archbishop, seeing that the churches were literally packed with people, said with astonishment: 'This is like in the time of Jesus'. The popularity of inner healing teaching became so massive that a special genre of 'healing mass' emerged in a number of parishes. In 2009, while giving introductory lectures on the anthropology of ritual in the faculty of theology, I had discussions with students on the issues of Christianity and noticed that the language of contemporary popular piety had come to be dominated by the vocabulary, discourses and ideas of the IHM.
Today the IHM is well organised and in large part takes a form which is reminiscent of psychotherapy, but with a Pentecostal approach. Trained groups, or individuals (usually in pairs) counsel those in need, who come with problems ranging from, for example, recurring intergenerational ailments and physical disease to depression, misfortune, family problems, post-abortion syndrome, addiction or divorce. Almost anything can be moulded to fit the inner healing framework, thanks to its specific process of narrative construction. The process is sometimes facilitated by means of a questionnaire which has to be filled out prior to the counselling/prayer session. The questionnaire prompts the respondent to outline a narrative, based on which a diagnosis of the 'spiritual wound' is defined. The concept of 'healing' is broadly defined and the healing process is adjusted to the content of the narrative. The inner healing programme itself is a sequence of free counselling sessions during which personal issues are tackled extensively. Pentecostal ritual practices (such as intercessionary prayers, prayers in tongues, prayers of ould dream of. Scenes of notorious possessions, exorcisms, peculiar anomalies with electronic sound equipment during IHM rallies deliverance and using the so-called 'spiritual gifts', including the 'discernment of spirits', 'words of wisdom', 'prophesy', 'words of knowledge', and so on) follow each counselling session.

Moreover, the inner healing discourses grew out of the Pentecostal framework and have become an inseparable element of regular, parochial, lay activity. Quite a number of the parishes in Lithuania now have a monthly inner healing mass and parochial inner healing circles. The monastery of St John (in Vilnius) utilises inner healing for the catechetical formation of the lay community.

\section{From the Catholic Charismatic Renewal to the Inner Healing Movement}

For an anthropologist, this inner healing 'stuff' was a fascinating phenomenon. It offered more unique 'field' experiences than most anthropologists could dream of. Scenes of notorious possessions, exorcisms, 
peculiar anomalies with electronic sound equipment during IHM rallies, with later discursive interpretations concerning the ongoing spiritual struggle; queues of people lining up for counselling and confession, usage of almost forgotten Catholic practices and atypical applications of 'sacramentals', conversions, multiple prayer parties for those in need, outbursts of shouting, tears and roars, fascinating teachings, and tense relationships with the ecclesiastical authorities... And all of this in one movement, and sometimes in one place. I was thrilled, thinking I had found a unique religious phenomenon which no one had researched or recognised for its scholarly potential. However, after a few years of inquiry I had both a revelation and something of a disillusionment. I recognised that all of this, just as in the case of Matthew Engelke (2007), is merely a local development of Pentecostal Christianity. The latter I never intended to research. Moreover, the trend of this discursive Pentecostal development, having diverse expressions, is likely to go global.

The link between the CCR and the IHM unfolded when I stepped back and asked myself how it happened that one single discourse - the healing discourse - has captured the imagination of local Catholics, lay and clergy, and penetrated popular Catholic practices. I brought this query to one of my informants, an internationally famous nun by the name of Sister Briege McKenna. She was visiting Lithuania to contribute a paper at a conference on inner healing issues (or so I was told). To my surprise, during the interview she denied (with laughter) being involved in the IHM. She did, though, point out that its healing discourse and practices were originally nurtured by the CCR, with which she very much does associate. The two phenomena had instantly been bridged. The people who invited the nun had identified her as representing a version of the IHM, while she herself denied any relation with it and identified with the CCR. However, neither the organisers nor the audience discerned any dissonance between the two phenomena. The difference apparently resided only in my head. Despite its thrilling, frenzied nature, which made it look unique, the IHM would have to be perceived and researched in relation to the CCR and thus in the context of global Pentecostal trends.

\section{Transformations of forms of Lithuanian Catholic piety}

During the Soviet era, the state put a great deal of effort into preventing religious practices, but in one way or another many families managed to keep their faiths. After the collapse of the Soviet Union, Catholics in Lithuania, who constitute the religious majority (about $79 \%$ of the population in 1992 and $77.9 \%$ in 2012), became free to practise their faith without restrictions. Therefore, the church hierarchy, many of whom were former dissidents, turned to reestablishing the form of the Catholic faith that they had been struggling for. The pre-Soviet occupation version of Catholicism (of the 1930s) was a mixture of Roman Catholic teaching, some nationalist tendencies and pre-Christian practices. The reintroduced faith of the post-Soviet period, however, was a kind of 'conscious' or 'informed' orthodox Catholicism with a rather fixed, 'prayer book' form of piety and with the clergy in charge.

In the 1980s, new religious ideas and movements started to leak in. One group of such were the Pentecostalist movements as we know them. The first groups of Catholics who were fascinated by the Pentecostalist message yet remained devoted to their own faith appeared in the 1980 s and early 1990 s. Local clergy slowly discovered that Pentecostalism and the Catholic faith were compatible, embracing the global Catholic trend (see also Csordas 1997a: 17).

Traditional Catholicism in Lithuania had a clearcut distinction between its hierarchy and the laity. No religious activity occurred without the supervision of the clergy. All forms of piety were predominantly fixed, coming from the Roman Catholic and vernacular traditions. There was little space for spontaneity. However, the emergence of the CCR brought many novelties.

The first and major distinction was that the CCR was an urban, middle-class movement (cf. McGuire 1982: 6) and had a huge influence on both the religious hierarchy and the lower-class population. Lay people organised themselves and would come to the members of the hierarchy for recognition. Their religious energy and explicit loyalty apparently won the hearts of the ecclesiastical authorities.

Another novelty was that the CCR shifted attention from traditional practices and beliefs to spiritual experiences; spontaneous prayers, reading the Bible as the word of God, 'non-mediated' communication with God, personal conversion and various other spontaneous activities. Before the CCR, the idea 
of baptism in the Holy Spirit was known only as a story from the Bible. At first the clergy and many lay people perceived the CCR, and the 'gifts' of the Holy Spirit (prophesy, speaking in tongues, healing etc.), as a frightening anomaly, or a psychotic phenomenon, incompatible with their 'old' faith. However, there was a growing participation of the clergy in the Lithuanian CCR and a labelling of figures of traditional Catholic piety, like the Virgin Mary, St Francis, St Thomas Aquinas and various Catholic mystics as early 'charismatics' (see Laurentin 1977: 192). By invoking these figures, the CCR was being 'normalised' and people were being encouraged to embrace new experiences 'with God'.

\section{Transformation and the new forms: piety, language and modes of operation}

While discussing with one of my informants the irreversible changes that the CCR had brought to the local church, I was told that the CCR is not a movement, it is a renewal'. When I asked if there were signs of its decline, I was corrected. She told me that in 2007 the international CCR conference took place in Italy where it was officially stated that the CCR had 'accomplished' its mission of renewing the church. She referred to the main conference speaker's 'appealing' thought that the CCR had been there for 40 years, the same number of years that the Jews wandered in the desert. Now it was time for it to 'dissolve' into the church.

Indeed, the legitimisation of the CCR in the postSoviet Catholic milieu significantly transformed the face of popular piety in Lithuania. Pentecostal practices penetrated everyday forms of piety, becoming not an alternative spirituality but an integral part of local Catholic practices. I argue that it is exactly the Pentecostal affect that paved the way for the healing discourse and practices to appear and develop into what is now known as the Inner Healing movement.

To describe this change, we have to discuss its three most salient aspects: 1 ) the mode of operation of the CCR, 2) the domestication of the new forms of piety, and 3) the development of a new religious language.

\section{Modes of operation}

In post-Soviet times, religion re-entered the public sphere having incorporated some nationalist language, formulating the Catholic faith (along with an idea of family) as being an aspect of Lithuanian-ness. The CCR, however, brought a novelty that prevented the latter trends from crystallising. One Canadian Lithuanian, a CCR activist, frequently visited Lithuania, spending most of his time with his local CCR friends, but not with his Lithuanian relatives. I asked him why he chose friends instead of relatives. He answered: 'the spirit is thicker than blood'. This is a good example of how Catholic identity became detached from family identity, and how the same happened in relation to the discourse of the nation.

Rallies on demand took place all over the region. Some typical 'shows' that I observed consisted of: 1) worship with music, 2) short performances of drama or mime with metaphorical religious content, 3) testimonials of conversion, 4) encouragement to pray a common conversion prayer, 5) introduction to the CCR and its forms of piety, and 6) prayer sessions with laying on of hands for those who had a petition to God. All this effort to domesticate the CCR finally proved fruitful, and charismatic prayer groups flourished in the parishes. For many parsons, to have such a group in their parish was an indication of being progressive and advanced.

Amidst a flood of American and Western European charity funds pouring into the region, CCR members quickly learned the language of 'projects' and entered the so-called 'third sector'. Therefore, the CCR swiftly transformed into a number of lay religious organisations which organised public events, published books, and organised educational campaigns, conferences, seminars and summer schools. While the clergy became a minor player in this development, the laity strove to bring them in more (to the CCR experience) since they wanted the recognition of the official church. Local bishops took these unprecedented lay initiatives seriously. On numerous occasions they publicly recognised the validity of the CCR and pushed the recognition down in the hierarchical pyramid. As a result, church-recognised lay religious NGOs proliferated throughout Lithuania and established a new kind of Catholicism.

However, it would be a mistake to assume that this had the effect of pushing the traditional forms of piety to the margins of Catholic practice. In fact, both of these forms became recognised Catholic spiritualities in post-Soviet Lithuania. The difference was that traditional Catholicism operated as a cultural heritage (combined with family and national discourses), while the CCR operated according to the rationale of 


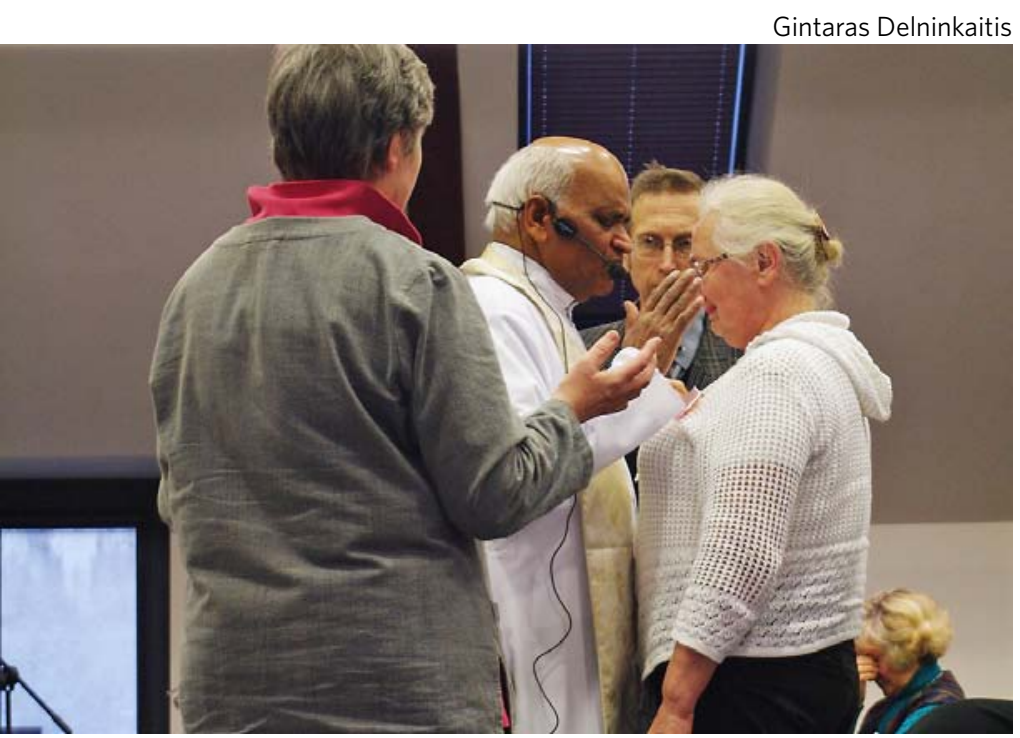

Intercession prayer during the inner healing retreat in Kaunas city with Fr. Z. Thudippara (India), September 2014.

an NGO (the new kind of structural, organisational mode). This latter mode of operation opened the way for the global trend of the CCR, and that created various funding opportunities, helping to bring speakers, programmes and projects into the Lithuanian context. Most of my random observations of the later CCR took place in various types of summer schools (called summer camps), and weekend or evening meetings. All of these were organised and funded by NGOs established by CCR members. The IHM emerged steadily, as if via a newly-paved road, using the 'logistics' and modes of operation of the CCR. It entered the CCR's parish or non-parochial prayer groups, and seized the attention of CCR conference attendees. It appears that many CCR speakers around the world at a certain point began putting emphasis on one of the Pentecostal practices, namely the healing practices, and started coming to Lithuania as both Catholic charismatics and as those spreading the concept of healing. IH was slowly becoming the dominant theme at Lithuanian CCR public events. If it was not the dominant theme, then it was the main prayer practice at the end of almost all of CCR events.

\section{New practices and forms of piety}

By contrast with the static character of traditional spirituality of Lithuanian Catholicism, the CCR brought in a new concept - baptism in the spirit. This is a purely experiential act of piety whereby a person appeals to the Holy Spirit to come down to him or her. In most cases, I have witnessed this act as a communal practice where a community of people lay their hands on the body of an individual and pray to the Holy Spirit to 'baptise' him/her. There were people who claimed that some kind of change had taken place after this prayer.

The baptism in the spirit is an experiential, non-ecstatic phenomenon as if 'rite of passage' of Pentecostal Christianity. Most narratives include mention of the feeling of what we could call a dual inclusion' - a feeling of the person being 'within' God and of God being present within the person. There is reference to the New Testament texts of, for example, Romans 8:9 and 1 Corinthians 6:19, which speak about a person as being a sanctuary of God, filled with his spirit, as being 'immersed' in God. The feeling of inclusion for many is accompanied by an experience of serenity, peace and security in everyday life (or so they say). As in Laurentin's study, my documented narratives describe the experience of baptism in the Holy Spirit not as an instant, measurable change, but as an all-encompassing experience of a 'renewal' of life with an abiding sense of the presence of God. This meta-experience includes a number of other experiences, two of which are important to mention here: 1) experiencing the 'power of God' as a 'dynamic energy of life' (Laurentin 1977: 30); and 2) a 'love' experience: being loved by God and feeling love for other people; that is, reconciliation. An individual experience of love for one's social environment inspired a range of relation-restoration practices through analysis of conflict situations, leading to practices of forgiving and apologising. The narratives that I have collected describe family reunions involving various relatives, including parents and children, and also restored friendships. The reconciliation discourse and practices, it appears, became one of the core elements of the later IHM. This garland of extremely positive experiences contributes to the therapeutic effect of the IHM.

Some of the charismatic practices resemble contemporary religious mysticism. McGuire (1982: 32-4) describes this tendency as an environment of 'mystery and miracles', which is the Pentecostal response to a 'disenchanted world' (in a Weberian sense). McGuire uses Peter Freund's term 'holy coincidence' for the phenomenon that is experienced, and these experiences are converted into a narrative. In what follows an example of a 'holy coincidence' documented during the fieldwork is described.

One CCR member told me that he had fallen 
deeply in debt due to a series of family misfortunes. During one CCR rally, a stranger approached and handed him a package with money saying that God had told him to do this. In the package, my informant found the exact sum he had to pay to his creditors. He assured me that no one knew about his debt because he perceived this indebtedness as shameful, and that he had never before met the man who gave him the money.

Another recorded story again highlights the question of experiencing religious mysticism. One informant told me that during a big CCR rally she was 'serving as a worship minister' and therefore had a place on the stage behind the altar. According to her, the event was 'full of the Spirit' [CCR slang denoting an 'uplifting' cognitive and emotional state]. The Mass was celebrated by a well-known priest, a CCR member, with a reputation as a very devoted and pious Catholic. My informant told me how she suddenly noticed that the ritual came to a halt at an unusual point, where it was not supposed to stop. It happened right before the particular musical moment at which she was to step in and sing. When she looked at the priest, she noticed him firmly holding the edge of the altar with his feet in the air above the floor. In other words, the priest was levitating. She was rather embarrassed telling me about this: '... it is not something you would normally discuss with anyone. I told only few people about this. Now it sounds awkward ... I know. ... But at the time, in the midst of everything that was happening around me, it didn't seem awkward at all.' Levitation is a classic element of Christian mysticism, so informants perceived this as a 'natural' manifestation of the same Spirit that has acted on various Christian mystics of the past.

The reliability of these narratives is not a concern here. Stories about peculiar and spontaneous 'outpourings of the Spirit' are a separate genre of the Pentecostal 'oral tradition'. However, what is significant is that the CCR, as an 'experiential' phenomenon, prepared the soil for various forms of religious mysticism to take place. Manifestations of the supernatural became at least theoretically possible as the 'moving power' of God and other spiritual agents.

Felicitas Goodman (1972) argues that religious experiences necessarily involve a (non-pathological) altered state of consciousness. It is reasonable to assume that this is exactly what the CCR experiences are likely to generate. In these experiences, perceptions of the natural and supernatural overlap. The

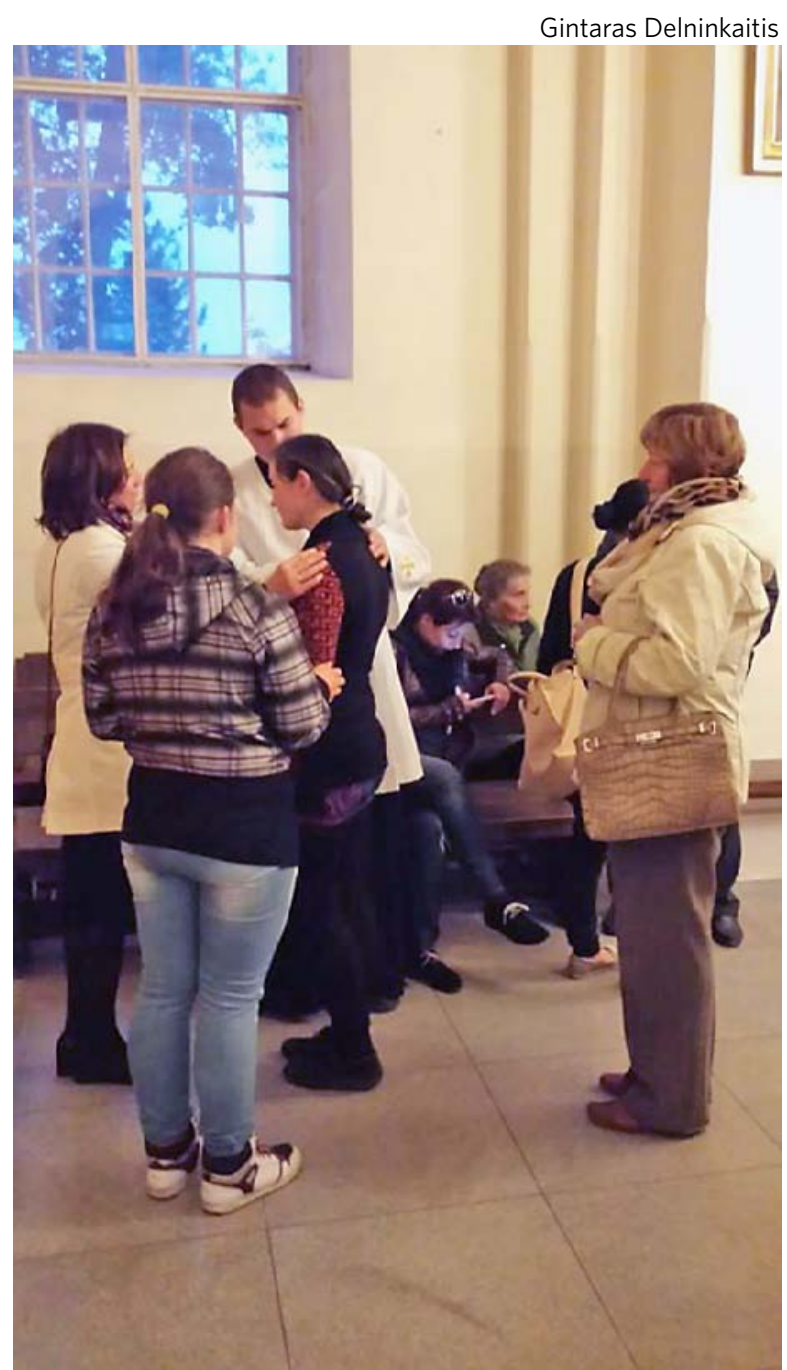

An inner healing service at the Assumption of Christ parish, Utena, Lithuania, November 2013.

premise of the presence of the supernatural is always there among the members of Pentecostal Christianity. My informants would sometimes organise a CCR event without having funds available, with a certainty that God would solve the problem because they were doing 'God's work'. When occasionally some huge unexpected financial donation would come, mostly from Western charity organisations, they would see this as a demonstration that God was in charge and taking care of everything. Sometimes it seemed as if it would have been more surprising for them if the unplanned funds had not have arrived.

The IHM has inherited an attitude which is geared towards, or an expectation of, the supernatural. Taking into account the fact of the altered state of consciousness may help to understand unusual experiences of religious healing. In other words, Pentecostal Christianity - and thus the IHM - pre- 
pares people for unusual experiences. If and when they occur, they seem to be expected, or even anticipated, rather than surprising. Moreover, these experiences serve as a confirmation of the moving power of God and his presence. How this alteration of consciousness may affect the therapeutic process is a theme for another article.

As mentioned earlier, healing practices gradually became the characteristic feature of the CCR, or at least an inseparable feature of its customary communal prayer practices. This was often accompanied by faith-altering testimonies (a genre of storytelling) and peculiar happenings such as shaking, screaming, crying, or the experience of a phenomenon known as 'resting in the Spirit' (a motor disorder). Most of the prayer meetings I witnessed had a tendency to stress (physical or psychological) healing issues. These practices, it seems, loosely conceived what later crystallised into a separate movement. That is how, I assume, the CCR paved the way for the later phenomenon of IHM to appear.

\section{New religious language}

The final innovation that I want to discuss is the formation of a specific religious language - a narrative 'tradition' including the genres of ritual language and a distinctive form of storytelling. Most of the literature on, and ethnographical studies of, Catholic Pentecostalism accurately note the significance of specific language for the CCR. Csordas calls this phenomenon 'speaking the Kingdom'. He notes that: 'Catholic Charismatic ritual performance is characterised by a marked linguisticality, in that most of what goes on is verbal' (Csordas 1997a: 158). However, I suggest that the role and transformative effect of religious language is a slightly under-theorised phenomenon of Pentecostal conversion and healing practices.

The most comprehensive account of CCR language is found in Csordas' Language, Charisma and Creativity: The Ritual Life of a Religious Movement (1997a, 157-201), in which he organises it under the several headings. However, what is important for my inquiry is the appearance, specificity and transformative effect of the CCR ritual language in the Lithuanian Catholic context.

The appearance of the specific ritual language was a significant change in the local Catholic environment. I noticed that it was learned by converts spontaneously and intuitively, not systematically, although some cases of 'translation' from everyday to CCR language were evident. I suppose that the transformation of language is an inseparable part of the CCR conversion phenomenon and it works in a circular-generative way. The change of a convert's social environment is marked by the change in his common language (the vocabulary and manner of talking). This, I have noticed, simultaneously has an impact on both the convert and his previous environment. A conversion state of consciousness is accompanied by a strong individual religious experience and is narrated to other converts in the language of their new environment. Therefore, conversion is not only an experience, it includes a language that makes this experience cognitively perceivable or tangible. And this generates a further effect of novelty, change and discontinuity, because their previous environment often reacts to this change negatively. One person I had personally known for a long time had previously used a wide variety of Russian-Tatar swear words. This was an inseparable part of his daily language. However, when I met him within the CCR context, something was different about him. His language was unusually 'mild'. He later asked me if I had noticed any change in him. I was embarrassed and hesitated, but he rushed to tell that his old habit of swearing had disappeared the very next day following his conversion and that this had been noticed by people around him. He spoke about this as if he was the witness of a miracle.

Another interesting case showed the translational capacity of the CCR language. During one public meeting several people had been giving 'testimonies' of 'God's Grace' (God's permanent presence and guidance). Most of these stories were spoken fluently in the CCR religious language, but one recent convert, a businessman, was struggling with the language and the message. He appeared to lack rhetorical skills, but there was something else missing. He was telling a story about how he had been making a large-scale international business deal in dairy products and had a bad feeling about it. After double-checking the documents, which he did out of simple intuition as the documents had been confirmed to be fine, he suddenly discovered a well-hidden fraud. Consequently he cancelled the deal, saving his business from bankruptcy. Although he attempted to bring in the issue of God, there were no typical CCR words or narrative tropes concerning guidance from the Spirit, receiving the word from God, and so on. The whole narrative 


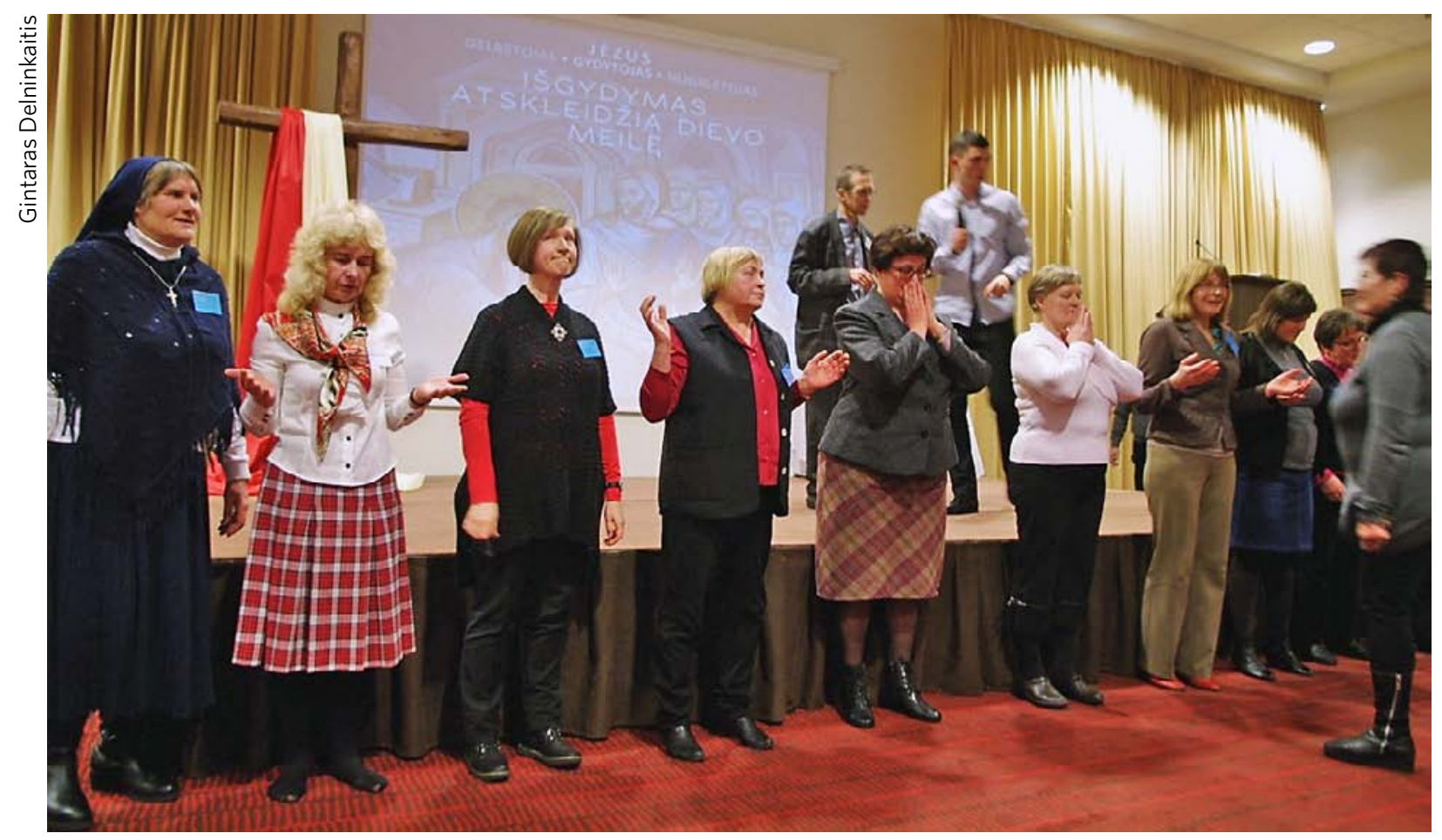

Prayer teams in preparation for the intercession prayers and counselling. The Inner Healing seminar in Kaunas city, February 2013.

sounded inconsistent, like a poorly-mastered story of the 'I Got Lucky' kind. However, later that night I was told by another CCR person that this man 'doesn't know how to say this yet' and that earlier, in private conversation, he had described how he intuitively perceived this luck as being the result of ongoing help from God which he had experienced after his recent conversion. Thus the same story was fluently narrated to me in the CCR language, using theological concepts and making the experience consistent with the terms of the 'economy of salvation'.

CCR ritual language is not merely the consequence of conversion experience; it also has the capacity to translate religious intuition into theological logic, rendering the intuition re-conceptualised, reasonable (based on a scheme of cause and effect), understandable and explainable. This, I assume, is the phenomenon that simultaneously generates and reinforces the conversion itself, because the better the man understands his own 'altered' experience, the stronger its effect is. This experience is later summarised in metaphorical language, by means of which a fluent and inspiring narrative is constructed which is called a testimony. Subsequently through the tradition of Pentecostal storytelling, it inspires new conversions.

In the IHM, I found that the use of language and modes of narration play the very same role in firstly, translating the ailment, misfortune or bad feeling into religious language, and formulating a diagnosis of what is to be healed; and secondly, constructing the healing process within the discursive constraints of a narrative. The whole language and narration process is the same in the CCR as in the IHM practices. Whatever inexpressible experience one may have is translated into a narrative using religious language. The narrative 'sorts things out' and explains what and why. Thus the translation process enables an individual to accept the experience and even provides a relatively clear cause and effect scheme. It sorts random life issues into categories, such as, say, a problem of addiction. If the problem is found to recur across generations then it is said to be due to the transgression by some ancestor of the first commandment of the Decalogue; that is to say, a sin of idolatry. They discuss what forms of idolatry there are and look for signs of it in an individual.

The process of narrative construction undoubtedly is an indispensable element of the externalisation of a trauma or problem, which is a well-known method in narrative psychology (see White 2007). Thus, the CCR language utilised in the IHM does both: using religious language, it narrates the 'ailment', thus, externalising the problem (a therapeutic process in itself), and then subjects it to the Pentecostal healing 
practices. Considering the altered state of consciousness which goes with an expectation of the supernatural, all this is likely to have some therapeutic effect.

\section{The salience of religious experiences against epistemology}

Charles Taylor's pithy remark on Pentecostalism; namely that Pentecostal experiences are often bodily experiences, gives a very deep insight into the nature of Pentecostal Christianity (see Taylor 2007: 767). However, what is even more significant is the fact that Pentecostalism is a form of 'experiential' Christianity, and among the experiences of which it comprises, the bodily ones are indispensable. This makes Pentecostal Christianity an experienced, rather than an epistemologically-learned religion. Traditional Lithuanian Catholicism was primarily epistemological, with religious experiences coming, or not coming, later. We may say that epistemological religiosity disembodies religion. For Pentecostal religiosity it is the other way round. Religious experience comes first, followed by religious epistemology. It is reasonable to assume that Pentecostal Christianity, in as much as it 'sells' unmediated access to God, brings religion back to the human senses, especially (but not exclusively) to the bodily senses.

The following ethnographic example illustrates how the emphasis in the CCR shifted from religious epistemology to (Pentecostal) experiences, which for their part brought about the therapeutic practices and the IHM.

During my observations of the CCR, I attended several weekend seminars called the 'Course of Philip'. It was one of the new modes of operation of religion - an interactive seminar where religious content was thoroughly organised and divided into talks called 'teaching', accompanied by interactive activities called dinamikos (dynamics). During the dinamikos all the participants were actively involved in communally and individually experiencing the content of the teaching. The common mood of the seminars was always uplifting. The audience was always involved in having a good time between sessions and during breaks. Laughter, smiles, singing and joking were common throughout the course. However, I noticed that during one of the last dinamikos, dramatic changes would always occur in mood of the attendees. During the teachings about baptism in the Holy Spirit, it had always been stressed that this is an experience of the transformative power of God in one a good tmy rephrasing]; it is available to everyone and God desires it for everyone. However, one must open oneself up to it. To stress what was said, they applied visualisations. They poured water into an empty transparent bowl, explaining that the Holy Spirit is water and the bowl is an individual who is open to it. This demostration was accompanied by a contrasting (and unexpected) demonstration of water being poured onto an empty but covered bowl. The water, thus, splashed off the covering in all directions and the bowl remained empty. This scene always had a noticeable effect on the audience. There followed an explanation of what in our lives constitutes the covers that keep out the Spirit. Summarising briefly, they were identified as sinful acts (explaining what these are) and unforgivingness (unwillingness or inability to forgive or accept forgiveness). After these explanations, the attendees were invited to come forth (to the prayer teams) for the prayer of baptism in the Holy Spirit. Prior to that, the audience was led in a vocal prayer of forgiveness with soft background music. The speaker would slowly read the prayer, mentioning, for example, parents, family members, relatives, friends, schoolmates and teachers, employers or neighbours. The prayer mentioned the most common conflict situations, abuse and traumas, and directed people to forgive or ask for forgiveness. Then the prayer turned to naming happenings and misfortunes, bringing forward any frustration that it had (possibly) caused, and forgiving God for all of this. The most striking thing was the psychological depth of those 'guiding prayers' of forgiveness and reconciliation. In a calm voice against a background of quiet music the speaker very slowly, with long silent pauses, led participants to analyse the inner depths of the human personality and of their social, psychological and spiritual experiences.

This stage of the seminars, as I noticed, always marked a turning point in the prevailing mood. While the queues of people were lining up before the prayer teams, many attendees became introverted, concentrated; some were sad or crying. Some cried loudly and, occasionally, at the top of their lungs. This part of the seminar was always the longest (2.5 to 3 hours) and apparently was the core of the day if not of the seminar itself. Sometimes it was not foreseen that the time for the prayer session would be so long, but the main predisposition of organisers was to respond to the needs of every participant. Overall, 
these seminars seemed like a thorough preparation for the final stage of Pentecostal experiences. The time devoted to religious experiences wasn't placed under much constraint in the schedule as the prayer session was always the last stage of all the events that I observed. In other CCR cases observed, the preparation for Pentecostal experiences was not as intense. A short inspiring talk aimed at provoking the wish to experience the power of God would be followed by a very long experiential practice. Outbursts of emotion would frequently happen in response to these practices.

Sometimes during public prayer sessions someone with a microphone would lead a prayer, emphasising the healing discourse. The emphasis was rarely on physical healing alone. Rather the ultimate need for help from God would be 'translated' into a request for healing. They spoke about the healing of the soul, about spiritual wounds, healing of the body or of psychological trauma, healing the 'heart' (emotional wounds) and God was even asked to 'heal' the situation. For some reason, God was perceived exclusively as a healing God.

It would appear that the CCR experience unleashed a catharsis that had to be dealt with, taken under control, organised and directed. Thus the prayers involving the healing of memories, later known as the inner healing prayers, slowly became the defining feature of the local CCR. The growing popularity and demand for $\mathrm{IH}$ practices, along with the growing number of healing narratives (testimonies), required a guiding theory. According to Csordas, this was developed in the CCR in the US. Some psychologists and psychiatrists, also members of the CCR, were asked to develop a kind of therapeutic theory incorporating religious content (see Csordas 1997b: 40). What is important in all this is that the religious experience of IH was the catalyst for development of the theory and not the other way round. The same was true for Fr. Raniero Cantalamessa. This former preacher of the papal household made a tremendous effort to 'find' the roots of the Catholic Pentecostal experiences in the depths of Catholic theology. Thus we see that Pentecostal Catholicism, like many other forms of Pentecostalism, is an experience first, and only later becomes rooted in religious epistemology, as if discovering (not always easily, though) that it lay hidden there all the time.

In tracing the development of religious change in Lithuania, we see that the emergence of Pentecostal

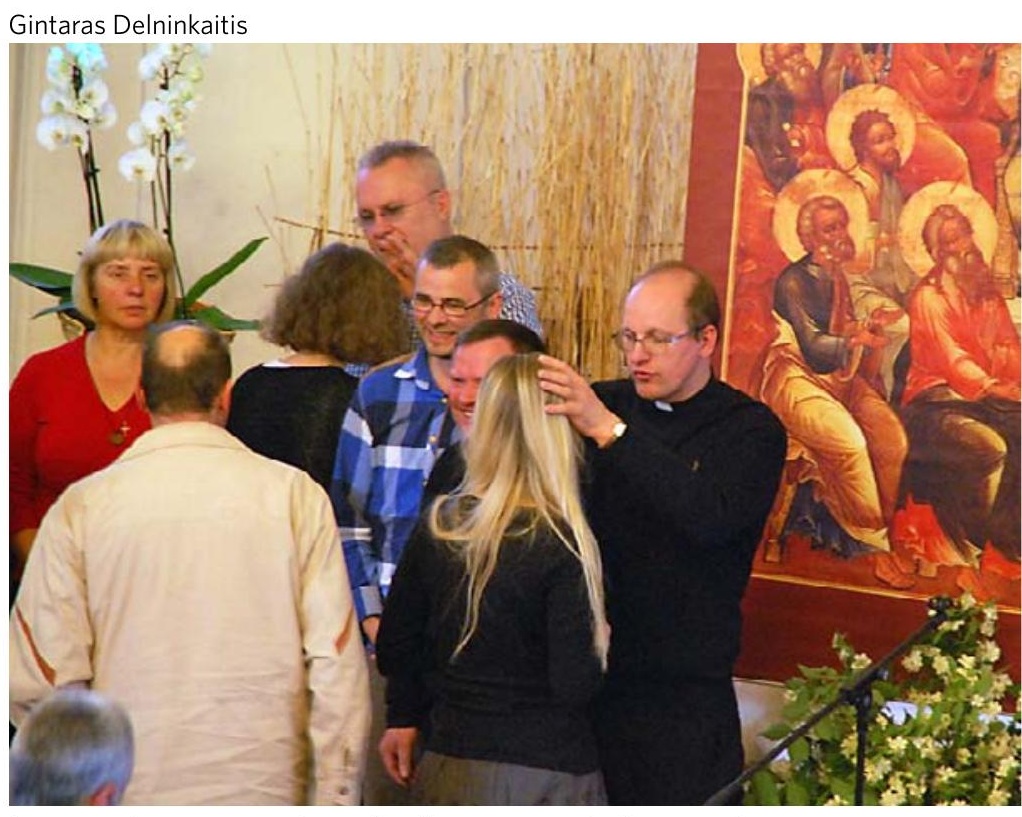

Intercession prayer at inner healing retreats in Kaunas city, November 2014.

Catholicism brought forward the experiential dimension of Christianity. This became a green light for healing practices to emerge and evolve as local phenomena, likely adjusting the vernacular realities of the people.

\section{Conclusions}

Sketching the dynamics of religious change in postSoviet Lithuania, with a narrow focus on the case of the Catholic Church, we get a picture of Catholic Pentecostalism entering the scene, radically transforming the Catholic context and developing further. In as much as it is a 'liquid' phenomenon, it is affecting the discourses, practices and attitudes of people rather than becoming an institution. For its part, the Catholic Charismatic Renewal movement has no problem with being absorbed and dissolved into the body of the established church. Rather, according to the people I spoke with, that is exactly what it strives for - a 'renewal'. Initially perceived as disturbing novelties, CCR practices have become an indispensable element of liturgical, pastoral and parochial activities. All this does not seem so surprising if we bear in mind the flexible and adaptable nature of Pentecostalism. What is striking, however, is the image of what 'post-Pentecostalist' Catholicism may look like. While the CCR as a movement is undoubtedly disappearing, it is passing on its legacy to the IHM, a movement which developed in its wake 
as naturally and smoothly as if it was destined to do so. And despite the fact that the first to engage with the IHM were almost exclusively Catholic Pentecostals, it is debatable whether the IHM today can be called a merely Pentecostal phenomenon. The initial Pentecostal emphasis on the immanent presence of God seems to have become a common religious disposition among many Catholics, not just in the IHM where manifestations of the supernatural are always expected. Despite the wide usage of Pentecostal ritual practices and 'spiritual gifts', the emphasis has already shifted from experiencing the Pentecost to experiencing the healing which is perceived as a natural function of the Holy Spirit. Thus the emphasis is much more on leading a genuine Christian life during and after healing. In other words, the IHM no longer looks for the signs of Pentecostal authenticity, but rather takes the Pentecostal message for granted and looks for the altered healing experiences that the CCR has highlighted. The new generation of those coming to the IHM may not know how to pray in tongues, but they know what it is they have experienced or are striving for - inner healing.

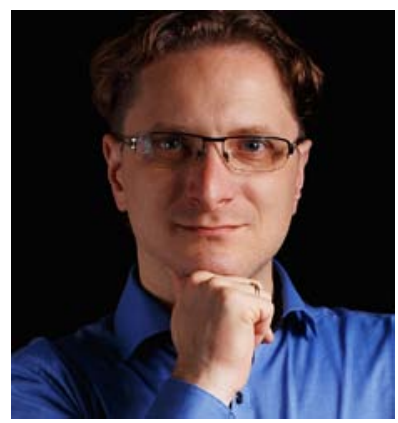

Saulius Matulevicius is a PhD student at the University of Vytautas Magnus, Sociology department. He studies Pentecostal Christianity and its vernacular developments. His field of interest in anthropology covers religion, secularisation, secularist politics and the post-secular, death and mourning, also media and organisational anthropology. He also is a lecturer at the ISM University of Management and Economics and Vytautas Magnus University.

\section{Bibliography}

Ališauskiene, Milda, 2006. 'The emergence of religion in a post-Communist society: the case of the city of Visaginas in Lithuania' in Religions Churches and Religiosity in Post: Communist Europe, ed. Irena Borowik (Nomos, Krakow), pp. 325-34

-2011. 'Freedom of religion in the Baltic States: a sociological and legal analysis' in Spaces and Borders: Current Research on Religion in Central and Eastern Europe, ed. Andras Mate and Cosima Rughinis Toth (Berlin, New York, Walter De Gruyter Press), pp. 133-51
Anderson, Alan (ed.), 2010. Studying Global Pentecostalism: Theories and Methods (Berkeley, University of California Press)

Bord, Richard, and Joseph Faulkner, 1983. The Catholic Charismatics: The Anatomy of a Modern Religious Movement (University Park, The Pennsylvania State University Press)

Cannel, Fenella, 2005. 'The Christianity of anthropology', Journal of the Royal Anthropological Institute, 11(2), pp. 335-6

-(ed.) 2006. The Anthropology of Christianity (Durham, Duke University Press)

-2010. 'The anthropology of secularism', Annual Review of Anthropology, 39, pp. 85-100

Csordas, Thomas, 1997a. Language Charisma and Creativity: The Ritual Life of a Religious Movement (Berkeley, University of California Press)

-1997b. The Sacred Self: A Cultural Phenomenology of Charismatic Healing (Berkeley, University of California Press)

Engelke, Matthew, 2007. A Problem of Presence: Beyond Scripture in an African Church (Berkeley, University of California Press)

Goodman, Felicitas, 1972. Speaking in Tongues (University of Chicago Press)

Hann, Chris, 2007. 'The anthropology of Christianity per se', Archives of European Sociology, 48, pp. 383-410

Lankauskas, Gediminas, 2008. 'On the charisma, civility and practical goodness of modern' Christianity in Post-Soviet Lithuania', Focaal, 51, pp. 93-112

-2009. 'The civility and pragmatism of charismatic Christianity after socialism' in Conversion After Socialism, ed. Mathijs Pelkmans (New York, Berghahn Books), pp. 107-28

Laurentin, Rene, 1977. Catholic Pentecostalism (Garden, NY, Doubleday and Company)

McGuire, Meredith, 1982. Pentecostal Catholics: Power, Charisma, and Order in a Religious Movement (Philadelphia, Temple University Press)

Pelkmans, Mathijs (ed.), 2009. Conversion After Socialism: Disruptions, Politics and Technologies of Faith in the Former Soviet Union (New York, Berghahn Books)

Robbins, Joel, 2003. 'What is a Christian? Notes toward an anthropology of Christianity', Religion, 33, pp. 1919

Schröder, W. Ingo, 2009. 'Hegemonic narratives and religious identity politics in contemporary Lithuania, Acta Historica Universitatis Klaipedensis XIX, Studia Anthropologica 3(19), pp. 49-57

Taylor, Charles, 2007. A Secular Age (Cambridge, MA, The Belknap Press of Harvard University Press)

White, Michael, 2007. Maps of Narrative Practice (London, W.W. Norton \& Co.)

Žilinskaite, Rlin, 2000. 'Religinii Vertybii Kaita Lietuvoje 1990-1999 metais', Kult metaiser, 6, pp. 213-51 